\title{
Senjata Api dan Maskulinitas dalam Cerita Pendek "The Man Who was Almost A Man"
}

\author{
Pita Merdeka ${ }^{1}$
}

\begin{abstract}
Abstrak
Maskulinitas adalah bagian dari kajian gender. Untuk memahami maskulinitas, kita perlu mengidentifikasi laki-laki sebagai pusat dari kajian ini dari beberapa aspek. Artikel ini akan membahas mengenai hubungan kepemilikan senjata sebagai simbol dari pencapaian maskulinitas laki-laki. Kemudian dalam artikel juga mengungkapkan mengenai berbagai macam sumber dan karya sastra bahwa memiliki senjata bisa memberikan kesan kekuatan dan maskulinitas (kelakilakian). Cerpen dengan judul "The Man Who Was Almost a Man" adalah contoh karya sastra yang mengambarkan kepemilikan senjata api sebagai sesuatu hal yang mendukung atau memberikan kemaskulinitasan pada laki-laki. Senjata api ditangan bisa berarti kekuatan dalam diri laki-laki. Hal ini digambarkan oleh tokoh utama (Dave Saunders) yang mengaggap senjata api sebagai simbol dari kehormatan. Sejalan dengan cerita pendek ini, ada beberapa banyak penyalahgunaan senjata api yang dilakukan demi meraih kehormatan (dihargai) dan maskulinitas dalam lingkungannya.
\end{abstract}

Kata Kunci: senjata api, maskulinitas, identitas, respek/kehormatan, kematangan

\begin{abstract}
Masculinity is a part of gender studies. To understand masculinity, it needs to identify man as the center of the study from various aspects. Here within the article, it would be discussed about the relationship between possessing arms (gun) as the symbol of earning men's masculinity. Then, it is implied from many sources and literary work, that possessing arms might give the impression of strength and masculinity. The short story entitled "The Man Who Was Almost a Man" is the example of literary work that gun possession will support someone in gaining his masculinity. Gun in hands means power or strength inside a man. It was showed by the protagonist (Dave Saunders) who considered gun as the symbol of respect and the real man thing (being masculine). Align with the short story, there are many gun violence happened in the name of gaining the identity of being called masculine and respect from people.
\end{abstract}

Keywords: gun, masculinity, identity, respect, mature.

\footnotetext{
${ }^{1}$ Fakultas Adab dan Humaniora, Universitas Islam Negeri (UIN) Syarif Hidayatullah Jakarta
} 


\section{Pendahuluan}

Berotot, kekar, berjambang, adalah beberapa bentuk fisik seorang laki-laki yang dibilang maskulin dilihat dari pandangan masyarakat secara umum. Ada lagi yang juga meng-identikan aktifitas kelaki-lakian sebagai hal yang maskulin atau membuat menjadi (keliatan) maskulin. Sebagai contoh: berolahraga seperti sepak bola, angkat beban, menembak, bungee jumping, dan olahraga lainnya bisa juga menampilkan kesan kelaki-lakian (mas-kulinitas) atau istilah populer dika-langan perempuan muda saat ini "cowok banget". Atau aktivitas fisik seperti yang terlihat dalam film Point Break yang dibintangi oleh Keanu Reeves dan Patrick Swayze, yang memperlihatkan aktivitas fisik yang dengannya mendukung hal kelakilakian/man-hood/maskulinitas seorang laki-laki seperti skydiving dan surfing. ${ }^{2}$

Sebenarnya menjadi maskulin tidak selalu berhubungan dengan physical apprearance atau yang berhubungan dengan aktivitas fisik, kepemilikan senjata baik senjata api maupun senjata traditional dapat menunjukan dan mendukung maskulinitas seorang laki-laki. Dengan memiliki senjata, akan membuat identitas seseorang menjadi lebih maskulin dan kuat, meskipun juga tidak selalu begitu.

Berbicara tentang senjata, jika di Indonesia kita kenal aneka senjata tradisional seperti Clurit, Rencong, Domplak, Keris, Kujang, dan lainnya yang dibuat untuk mendukung maskulinitas laki-laki pada jamannya, maka di Amerika dengan tujuan yang sama juga memiliki senjata api dengan aneka tipe dari jaman ke jaman. Biasanya senjata tersebut paling banyak dipakai untuk mendukung segala aktivitas keamanan dan pertahanan diri. Di Indonesia, bahkan ada juga yang menamai seorang penjahat besar dengan

${ }^{2}$ Yvonne Tasker, Spectacular Bodies: Gender, Genre and the Action Cinema. New York, Routledge, 1993, hlm. 163. nama senjata yaitu Klewang alias Mardij. ${ }^{3}$ Pemilihan nama itu berdasarkan kesadisan dan seringnya si empunya nama membawa senjata Klewang dalam aksi-aksi brutalnya.

Senjata-senjata traditional diatas sekarang memang sudah minim keberadaanya dan memang lama-lama tersingkirkan seiring dengan perkembangan senjata yang lebih canggih seperti senjata api. Bahkan beberapa diantara senjata itu kemudian hanya menjadi bagian dari sejarah yang terpajang dalam museum kita, salah satunya di Museum Pusaka di Taman Mini Indonesia Indah (TMII) Jakarta. ${ }^{4}$ Hal ini dikarenakan senjata modern yang lebih praktis dan lebih gampang digunakan meski dengan biaya yang jauh lebih tinggi.

Berbeda dengan negara kita, di Amerika senjata modern seperti senjata api bebas dimiliki oleh siapa saja yang telah memenuhi kriteria memegang

${ }^{3}$ Klewang adalah senjata tajam sejenis golok atau parang. Senjata inilah yang selalu dibawa ke mana-mana oleh panglima besar geng motor paling ditakuti di Pekanbaru Riau, XTC (Exalt to Coitus). Oleh karenanya, panglima besar geng motor itu dijuluki Klewang alias Mardijo. Dilihat dari keterangan disini bisa dilihat fungsi dari senjata yang bisa juga memberikan sebuah kesan khusus terhadap si empunya nama. Anggi Kusumadewi, Eko Priliawito, Klewang, dari Brebes Jadi Raja Geng Motor Pekanbaru: Klewang adalah senjata tajam sejenis golok atau parang. Vivanews, Rabu, 15 Mei 2013, 06:15 http://www.viva.-co.id/news/read/412754-

klewang--dari-brebes-jadi-raja-geng-motorpekanbaru, diakses 22 Juni 2013.

4 Museum pusaka dibangun dengan tujuan melestarikan, merawat, mengumpulkan, serta menginformasikan benda-benda budaya yang berupa senjata tradisional kepada generasi penerus agar merasa bangga terhadap bangsanya dan dapat dimanfaatkan bagi yang ingin melakukan studi penelitian mengenai senjata. Didalam Museum Pusaka terdapat aneka senjata dari jaman ke jaman serta penginformasian macam-macam kegunaanya dalam budayabudaya yang diwakilinya. Museum Pusaka dalam TMII,

http://www.tamanmini.com/museum/museumpusaka-2, diakses 23 Juni 2013. 
senjata api. ${ }^{5}$ Meskipun adanya kriteria kepemilikan senjata api, akan tetapi dengan banyaknya senjata api yang beredar di masyarakat Amerika dan mudahnya akses membeli senjata ap ${ }^{6}$ kemudian pula menimbulkan berbagai macam konsekuensi, baik itu dalam hal lemahnya kontrol kepemilikan senjata api maupun penyalahgunaan senjata api yang telah memakan banyak korban sipil yang bahkan kejadian penembakan itu bertempat disekolahan dengan target penembakan murid-murid. ${ }^{7}$

${ }^{5}$ Dikatakan bahwa pengontrolan yang ketat dari kepemilikan senjata api sangatlah dibutuhkan setelah adanya berbagai macam penembakan. Hal ini memang dikarenakan longgarnya pengontrolan kepemilikan senjata api. Ada banyak penyalahgunaan senjata yang bahkan terjadi dilingkungan yang mustinya steril seperti sekolahan dan kampus. Seperti contoh kasus pembantaian murid dan mahasiswa yang dilakukan Seung-Hui Cho dan Adam Lanza serta banyak kejadian penembakan lainnya yang ternyata pelakunya mengalami gangguan kejiwaan tapi dengan mudahnya memiliki aneka senjata api. Jeffrey Young. Gun Control Laws Fail To Keep Mentally Ill Away From Guns, terbit di website 17 Desember 2012 pukul 8:18, http://www.huffingtonpost.com/2012/12/17/guncontrol-mental-illness_n_2318421.html, diakses 24 Juni 2013.

6 Dijelaskan bahwa senjata api memanglah gampang untuk dibeli karena terbukanya akses pembelian dan kalaupun mau bisa saja membeli tanpa pengontrolan yang ketat. Bisa saja kurang dari satu jam kita bisa memiliki sebuah senjata api dengan harga hanya 25 dolar saja. Roman Espejo, American Youth: Opposing Viewpoints, United States of America, Greenhaven Press, 2003, hlm. 97.

${ }^{7}$ Film dokumenter Bowling for Columbine karya Michael Moore dibuat karena keprihatinan akan penyalah-gunaan senjata yang menyebabkan penembakan di SMU Columbine oleh dua muridnya sendiri dan lemahnya kontrol kepemilikan senjata api. Bahkan ada pula cerita mengenai membuka rekening bank dengan hadiah sebuah senjata api. Ada lagi contoh betapa mudahnya anak muda (juvenile) yang belum memiliki hak memiliki senjata, membeli peluru disebuah toko swalayan kecil dengan gampangnya tanpa adanya pengontrolan kartu identitasdari si penjual. Hal inilah yang kemudian menimbulkan penyalahgunaan senjata api yang merajalela di Amerika terutama dikalangan
Amerika sebagai sebuah negara dengan penduduk yang beraneka latar belakang, telah mempergunakan senjata api sejak beberapa ratus tahun yang lalu dimulai dari senjata api traditional hingga yang modern seperti dewasa ini. Bahkan dikatakan bahwa lebih dari 250 juta senjata api telah beredar di masyarakat Amerika secara bebas. ${ }^{8}$ Pada Awalnya senjata api dibawa oleh bangsa Eropa sebagai bentuk pertahanan diri akan tetapi kemudian pada kenyataannya seiring jaman, senjata api juga memfasilitasi berbagai peperangan di Amerika, baik pada masa pra kemerdekaan ataupun post kemerdekaan Amerika. Lebih lanjutnya senjata apapun itu baik yang traditional ataupun yang canggih (senjata api) semua bermakna sama sebagai pengambaran dari pertahanan diri akan suatu bahaya ataupun perlambang kejantanan-maskulinitas dari laki-laki.

\section{Senjata dan Maskulinitas}

Pengertian senjata adalah suatu alat yang digunakan untuk melukai, membunuh atau menghancurkan suatu benda juga sebagai alat perlindungan diri. Lebih lanjut senjata bisa berbentuk pisau, senjata api, pentungan/alat pe-mukul (club) dan lainnya. ${ }^{9}$

Sedangkan maskulinitas adalah konsep-konsep gender tentang perilaku yang dibangun secara sosial dan pada umumnya terkait dengan laki-laki. Reeser menyatakan bahwa nilai maskulinitas itu tidak hanya dipengaruhi oleh pergantian budaya yang ada disekitarnya tapi juga berubah setiap gene-

muda. Michael Moore, Bowling for Columbine, United Artist, United States of America, 2002.

8"In America today there are 250 million firearms in private hands, amounts to almost one weapon for every American. Two in five United States residences house guns." James Jacobs, Can Gun Control Work?, 2002, cover review.
9 Free Merriam
Webster
Dictionary, http://www.merriam- webster.com/dictionary/weapon, diakses 11 Juni 2013. 
rasi. ${ }^{10}$ Anthony Easthope mengatakan bahwa laki-laki adalah aktor-aktor aktif yang menghidupkan (dan dihidupkan oleh) mitos-mitos maskulin melalui cerita dan citra budaya dominan. ${ }^{11}$ Lebih lanjut pula Levant menambahkan bahwa maskulinitas akan berbeda pada setiap individu dari kelas sosial berbeda, ras berbeda, etnik grup beda dan lain sebagainya.

Maskulinitas hegemoni atau dominan adalah normatif ideal dari budaya perilaku laki-laki yang diperhitungkan untuk menjamin posisi dominan beberapa orang atas orang lain. Beberapa laki-laki lebih rendah (didominasi) dari laki-laki lain yang lebih kuat dan semua laki-laki meraih keuntungan dari subordinasi atau ketergantungan perempuan. Connell menamai ini dengan "dividen patriarki". ${ }^{12}$ Patriarki yang dimaksud adalah sistem kemasyarakatan yang menentukan seorang ayah/laki-laki sebagai kepala keluarga yang biasanya juga memiliki peran sebagai provider. Seorang laki-laki seharusnya mencontoh ayahnya dalam hal sebagai the next provider untuk keluarganya.

MacInnes menambahkan bahwa maskulinitas tidak hanya dari properti (laki-laki) sifat karakter atau aspek individu akan tetapi seharusnya dipahami sebagai sebuah ideologi mengenai seorang laki-laki yang seharusnya seperti apa dan kemudian hal ini (maskulinitas) dikembangkan oleh laki-laki dan perempuan untuk diambil hikmahdiaplikasikan-dalam kehidupannya. ${ }^{13} \mathrm{Jadi}$

10 Todd W. Reeser, Masculinities in Theory: An Introduction, West Sussex, Wiley Blackwell, 2010, hlm. 50.

11 John Storey, Teori Budaya dan Budaya Pop, (Terj), diterjemahkan oleh Elli El Fajri, Qalam, Yogyakarta, 2004, hlm 222.

${ }^{12}$ Connell dalam Ella Page, Men, Masculinity and Guns: Can We Break the Link? www.iansa.org/women, diakses 10 Juni 2013. Hlm. 2.

13 J. MacInnes, The End of Masculinity, Buckingham, Open University Press, 1998, hlm. 2. untuk memiliki sifat yang maskulin, seharusnya seorang laki-laki mencari sebuah ideologi mengenai laki-laki sebenarnya seperti apa yang dia inginkan.

Dalam bukunya, Bourdieu memperlihatkan aspek dari maskulinitas salah satunya adalah dengan senapan (senjata api). Senapan dipakai sebagai sebuah simbol dari kekuatan atau kejantanan dari seorang laki-laki. ${ }^{14}$

African-American males have adopted distinctive actions and attitudes known as cool pose . . Emphasizing honor, virility, and physical strength, the Latino male adheres to a code of machismo ... The American-Indian male struggles to maintain contact with a way of life and the traditions of elders while faced with economic castration and political trauma... Asian-American men resolve uncertainty privately in order to save face and surrender personal autonomy to family obligations and needs (14). ${ }^{15}$

Dari kutipan diatas memperlihatkan beberapa model atau tipe dari laki-laki secara umum didunia. Bentuk fisik orang Afrika yang biasanya berotot dan kuat biasanya lebih menekankan pada kehormatan, kejantanan, dan kekuatan fisik. Sejalan dengan itu, Darwin mengatakan orang yang ber-muscle (otot) dapat diasosiasikan dengan kekuatan, keperkasaan, kepahlawanan, kekerasan.

${ }^{14}$ Pengambaran dalam skema sinopsis oposisioposisi relevan me-ngenai hal kelaki-lakian dan hal kewanitaan. Pierre Bourdieu, Dominasi Maskulin (Terj.), Jalasutra, Yogyakarta, 2010, hlm 14.

${ }^{15}$ Lazur and Majors, 1995, dalam Ronald F. Levant "Men and Mas-culinity" dalam Encyclopedia of Women and Gender: Sex Similariies and Differences and the Impat of Society on Gender, United States of America, Academic Press, 2002, hlm. 722.

${ }^{16}$ Muhadjir Darwin, "Maskulinitas: Posisi LakiLaki dalam Masyarakat Patriarkis" Center for Population and Policy Studies Gadjah Mada 
Hal diatas didukung pula oleh teori Thorstein Veblen (1899/1994) yang menyatakan bahwa "kekuatan pendorong dari semua perilaku manusia adalah mencari apresiasi dan kehormatandihargai" lebih lanjut ditambahkan oleh Bourdieu bahwa tujuan utamanya adalah "menjadi eksis dalam ruang sosial, menduduki titik dimana dia menjadi individu dalam ruang sosial di sekelilingnya untuk mendapatkan kehormatan dan apresiasi". ${ }^{17}$

Pada dasarnya menurut Kimmel, manhood (kelaki-lakian) sebenarnya akan terus dan selalu berubah-ubah sesuai dengan perubahan sejarah. Manhood bukanlah manifestasi dari sebuah esensi dalam diri akan tetapi dibangun secara sosial dalam lingkungannya (dalam lingkup budayanya). Yang dimaksud disini adalah dimana sifat kelaki-lakian itu berkembang semua sejalan atau berbanding lurus dengan apa yang ada di lingkungan sekitar dia ada. ${ }^{18}$

Berikut adalah contoh nyata dari laki-laki yang menyalahgunakan senjata api sebagai bentuk dari keinginan untuk dihargai di ruang sosial yang ada disekitarnya. Contohnya kasus penembakan yang dilakukan oleh Eric Harris and Dylan Klebold di SMU Columbine ${ }^{19}$ yang menembaki teman-teman sekolahnya demi balas dendam karena merasa

University. S.281, June 24, 1999. http://www.cpps.or.id/images/S281.pdf diakses 28 Mei 2013, hlm. 5.

17 Pierre Bourdieu dalam George Ritzer and Douglas J. Goodman, Teori Sosiologi Modern. (terj) Jakarta, Prenada Media, 2003, hlm. 529.

18 Michael S. Kimmel., "Masculinity as Homophobia: Fear, Shame, and Silence in the Construction of Gender Identity" dalam Michael Kaufman dan Harry Brod, Theorizing Masculinities, Sage Publications, London, 1994, 120.

${ }^{19}$ Wikipedia: The Free Encyclopedia, Columbine High School massacre, https://en.wikipedia.org/wiki/Columbine_High_School_massac re, diakses 24 Juni 2013. dipinggirkan dari lingkungan pergaulannya.

\section{Analisa Maskulinitas dalam Cerita Pendek The Man Who Was Almost a Man}

Cerita pendek ini bercerita tentang seorang pemuda kulit hitam African American yang bernama Dave Saunders (17 tahun) yang sangat ingin menunjukan identitas maskulinitasnya dengan memiliki senjata api kepada orang-orang di sekelilingnya di daerah pertanian di Amerika bagian Selatan. Dave yang merasa terendahkan berusaha mencari cara supaya identitas dia sebagai laki-laki bisa tampak sehingga orang menganggapnya sama dengan laki-laki dewasa lainnya dan memperoleh ke-hormatan (honor) atau dengan kata lain respek (dihargai). Cerpen ini men-ceritakan pergolakan dalam diri Dave karena dianggap sebagai anak kecil. Inginnya, dia berubah dari anak laki-laki ke lakilaki sebenarnya.

Analisa cerita pendek dalam artikel ini dimulai dengan membahas judul cerpen, kemudian karakter lemah dari Dave Saunders dan permasalahan maskulinitasnya kemudian lebih lanjut membahas mengenai aspek maskulinitas dengan simbol senjata api yang membangun karakter utama. Sebagai catatan, bahasa yang digunakan tokoh utama (dalam kutipan) adalah bahasa Inggris African American pada tahun 1960an, hal ini dikarenakan Dave Saunders adalah anak laki-laki kulit hitam.

\section{Judul}

Tersirat dari isi cerpen bahwa maskulinitas hanya dimiliki oleh man bukan boy. Judul dari cerita pendek yang dibahas disini adalah The Man Who Was Almost a Man karya Richard Wright. Dilihat dari judulnya, kata The Man menunjuk pada Dave dengan Sex atau jenis kelaminnya. Kemudian tersirat juga bahwa Dave sebagai tokoh utama yang 
sebenarnya belum menjadi the real man atau yang dimaksud disini dengan katakata Almost a Man. Jadi bisa kita maknai bahwa makna yang tersirat yaitu laki-laki yang akan dibahas adalah laki-laki yang belum sepenuhnya menjadi laki-laki sebenarnya atau belum "benar-benar" laki-laki. Yang dimaksud laki-laki yang sebenarnya adalah memiliki sifat sikap maskulin laki-laki dewasa matang dalam pemikiran dan tindakan.

\section{Karakteristik Dave Saunders dilihat dari Fragile Masculinities Traits}

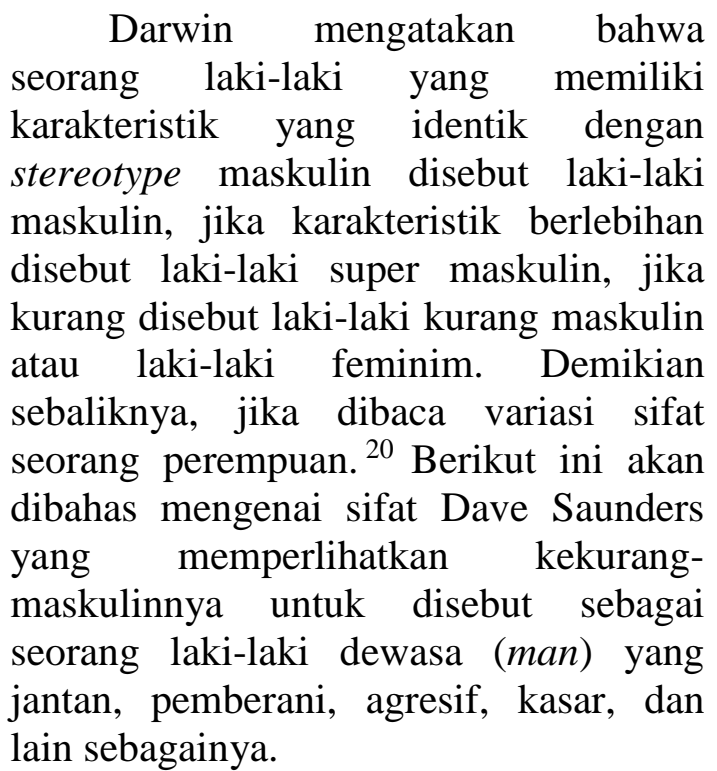

\section{Panggilan Boy (anak laki-laki)}

Definisi dari boy adalah a male child or youth atau seorang anak laki-laki (menurut kelamin) atau anak muda lakilaki. Lebih lanjut ditambahkan bahwa boy adalah a man, especially a young or relatively young one yang bermakna seorang laki-laki yang relatif laki-laki muda. ${ }^{21}$ Berikut ini adalah beberapa contoh kutipan dari beberapa orang yang memanggil Dave sebagai anak laki-laki

\footnotetext{
${ }^{20}$ Muhadjir Darwin, op. Cit., hlm. 3.

${ }^{21}$ Oxford Dictionaries. The World's Most Trusted Dictionaries.

http://oxforddictionaries.com/definition/english/b oy, diakses 23 Juni 2013.
}

(boy) bukan sebagai man (laki-lakidewasa).

\section{Ibu, Mrs. Saunders}

Dari beberapa kutipan dibawah ini memperlihatkan seringnya sang ibu memanggil Dave dengan panggilan boy. Kutipan pertama disini ketika Dave pulang dari toko Joe dengan membawa katalog senjata api dan sang ibu menyapanya.

"Where yuh been, boy?" His mother held a steaming dish of blackeyed peas. ${ }^{22}$

Kemudian pada kutipan berikutnya, Dave merayu ibunya untuk membelikan senjata api. Bisa dilihat bahwa menurut ibunya, Dave masih seorang laki-laki muda yang belum membutuhkan senjata api.

"Ah don care what Ah promised! Yuh am nothing but a boy yit!". ${ }^{23}$

Disaat yang sama sang ibu juga memanggilnya dengan boy saat memberitahukan bahwa kalaupun mereka memiliki senjata api, senjata itu bukan untuknya. Maksud sang ibu adalah kalaupun membeli senjata api, itu untuk ayahnya sebagai orang yang lebih matang sebagai laki-laki.

"Now don yuh try to maka fool outta me, boy! Ef we did hava gun, yuh wouldn't have it!" 24

\section{Ayah, Mr. Bob Saunders}

Contoh percakapan berikutnya adalah percakapan antara Dave dan ayahnya. Kutipan pertama terjadi saat sedang makan dan dengan tingkah konyolnya, Dave makan dengan langsung menelan makanan tanpa dikunyah terlebih dahulu hanya karena terpesona dengan katalog senjata api yang dia pinjam. Kemudian sang ayah

\footnotetext{
${ }^{22}$ The American Short Story Volume I, New York, Dell Publishing Co. Inc, 1977, hlm. 261.

${ }^{23}$ The American Short Story Volume I, hlm. 262

${ }^{24}$ The American Short Story Volume I., hlm. 262
} 
mengingatkannya akan tingkahnya yang konyol.

"Boy, how come yuh don quit foolin wid tha book $n$ eat yo suppah?" 25

Kemudian kutipan berikutnya ketika Dave melakukan hal bodoh dengan menembak seekor keledai tua (bernama Jenny) hanya karena mencobacoba memainkan senjata api. Dia menarik pelatuk dan menewaskan Jenny (keledai milik Jim Hawkins-sang majikan) yang sedang dia jaga. Percakapan ini terjadi setelah Dave menembak mati Jenny dan saat orangorang mengelilingi bangkai Jenny dan menggali lubang untuk menguburnya, kemudian kedua orang tua Dave dating menghampiri.

"Whut happened, Dave? Whut yuh done?" "Nothin."

father said. ${ }^{26}$

$$
\text { "C mon, boy, talk," his }
$$

\section{Joe}

Joe adalah pemilik toko tempat Dave membeli senjata api. Lihat contoh kutipan dibawah ini ketika Dave memberitahu Joe bahwa dia ingin membeli senjata api darinya:

"You ain't nothing but a boy. You don't need a gun." 27

Joe beranggapan bahwa Dave seorang anak laki-laki yang belum dewasa sehingga belum sepantasnya memiliki senjata api meskipun akhirnya dia menjual senjata apinya pada Dave. Lebih lanjut dilihat dari ucapannya, senjata api diperuntukan bagi orang yang sudah dewasa (man).

\section{Jim Hawkins}

Jim adalah majikan dari Dave. Panggilan boy disini merujuk pada Dave yang melakukan kelalaian sehingga menyebabkan kematian Jenny. Jim memberitahukannya untuk terus bekerja padanya dan setiap bulan membayar dua

${ }^{25}$ The American Short Story Volume I., hlm. 261

${ }^{26}$ The American Short Story Volume I., hlm. 264

${ }^{27}$ The American Short Story Volume I, hlm. 261 dolar untuk kerugiannya akan kematian Jenny; sang keledai tua.

"Well, you needn't worry about it, Bob," said Jim Hawkins to Dave's father. "Just let the boy keep on working and pay me two dollars a month." 28

\section{Kerumunan (masyarakat)}

Mereka datang untuk menonton kejadian aneh (kematian Jenny yang aneh) karena kematian Jenny yang diceritakan oleh Dave sangat sulit diterima akal sehat. Selanjutnya, setelah mereka tahu kronologi sebenarnya, segeralah mereka mentertawakan tingkah konyol Dave yang bermain senjata api tanpa tahu cara penggunaannya dan menewaskan seekor keledai. Kembali mereka memanggil Dave dengan sebutan boy.

"Well, boy, looks like yuh done bought a dead mule! Hahaha!"

"Am tha ershame." 29

Dari banyaknya kata boy (anak laki-laki) yang dipakai dalam cerpen ini, bisa dilihat bahwa semua beranggapan bahwa Dave Saunders masih anak dibawah umur atau laki-laki yang belum matang dan belum memiliki kedewasaan dalam berpikir dan bertindak. Hal ini sangatlah bertentangan dengan visi maskulinitas yang berarti kurangnya kelaki-lakian pada diri Dave.

\section{Kekanakan}

Dibawah ini akan dibahas mengenai sikap Dave yang kekanakan. Padahal untuk menjadi pribadi yang maskulin, seorang laki-laki memerlukan rasionalitas dalam pemikiran, open minded, terbuka, kadang kasar atau keras, dan agresifitas. ${ }^{30}$

Mebbe Ma will lemme buy one when she gits mah pay from ol man

\footnotetext{
${ }^{28}$ The American Short Story Volume I, hlm. 264

${ }^{29}$ Ibid., hlm. 264

${ }^{30}$ Muhadjir Darwin, op. cit., hlm. 3
} 
Hawkins. Ahma beg her $t$ gimme some money. ${ }^{31}$

Disini juga terungkap bahwa cara berbicara Dave memang masih kekanakan. Joe yang mengetahui Dave yang kekanakan mengoda Dave yang ingin membeli sesuatu. Joe tahu bahwa Dave tidaklah memegang uangnya sendiri akan tetapi ibunya yang mengendalikannya.

"Your ma letting you have your own money now?"

"Shucks. Mistah Joe, Ahm gittin t be a man like anybody else!"

Joe laughed and wiped his greasy white face with a red bandanna. ${ }^{32}$

Dave yang mengaku ingin lebih maskulin pun, masih saja terlalu manja pada ibunya. Dia lebih memilih mengungkapkan apa yang dia kehendaki kepada ibunya bukan ayahnya, bahkan dengan cara merengek.

"But Ma, Ah wans a gun. Yuh kin lemme have two dollahs outta mah money. Please, Ma. I kin give it to Pa... . Please, Ma! Ah loves yuh, Ma. ${ }^{33}$

Lebih lanjut Dave memang tidak dipercaya oleh ibunya, hal ini dikarenakan Dave anak yang belum matang dalam pemikirannya. Lihat kutipan dibawah ini yang menceritakan kenapa ibunya yang memegang uang hasil kerja Dave.

"Ah tol yuh $t$ git outta here! Yuh am gonna toucha penny of tha money fer no gun! Thas how come Ah has Mistah Hawkins t pay yo wages $t$ me, cause Ah knows yuh am got no sense." 34

Dari beberapa kutipan diatas bisa disimpulkan sisi maskulin dari seorang Dave Saunders adalah kurang maskulin sebagai seorang laki-laki yang hampir tumbuh menjadi laki-laki dewasa.

\footnotetext{
${ }^{31}$ Muhadjir Darwin, 260

${ }^{32}$ Muhadjir Darwin, 260

${ }^{33}$ Ibid., hlm. 262

${ }^{34}$ Ibid., hlm. 262
}

\section{Maskulinitas dengan Senjata Api}

Berlawanan dengan perempuan, lelaki yang benar-benar laki-laki adalah lelaki yang merasa dirinya harus berada di puncak kemampuan yang bisa diberikan kepadanya guna meningkatkan kehormatannya dengan cara mencari kemuliaan dan distingsi dikalangan public. 35 Banyak budaya yang memberikan slogan atau implikasi "membuktikan dirimu" menjadi "lakilaki sebenarnya" yang berhubungan dengan tata cara penerimaan dan resiko termasuk perilaku yang berhubungan dengan senjata api. ${ }^{36}$ Oleh karena itulah, Dave yang memiliki sikap dan pemikiran yang kurang maskulin kemudian mencoba mengubah identitas dirinya yang kurang maskulin menjadi pribadi/individu yang maskulin. Kemudian, dari cerpen tersebut terungkap bahwa untuk meraih maskulinitas di masyarakat sekelilingnya, Dave ingin memiliki senjata api.

One of these days he was going to get a gun and practice shooting, then they couldn't talk to him as though he were a little boy. He slowed, looking at the ground. Shucks, Ah ain scareda them even ef they are biggern me! Aw, Ah know whut Ahma do. Ahm going by ol Joe's sto $n$ git that Sears Roebuck catlog $n$ look at them guns..... Ahm ol enough to hava gun. Ahm seventeen. Almost a man. He strode his long loosejointed limbs. Shucks, a man oughta hava little gun aftah he done worked hard all day. ${ }^{37}$

Dari kutipan diatas bisa kita simpulkan bahwa Dave memiliki masalah dengan orang-orang di seke-

\footnotetext{
${ }^{35}$ Pierre Bourdieu, Dominasi Maskulin (Terj.). op. cit., hlm. 73.

${ }^{36}$ Small Arms Survey 2006 dalam Ella Page, Men, Masculinity and Guns: Can We Break the Link? www.iansa.org/women, diakses 10 Juni 2013, hlm. 3

${ }^{37}$ Ibid., hlm. 260
} 
lilingnya. Orang-orang menganggap dia immature atau kurang matang sehingga sering merendahkan dia karena dia dianggap masih laki-laki muda (boy). Merasa hegemoni kelaki-lakiannya direndahkan, dia berusaha untuk memenuhi kekurangannya dengan memiliki senjata api. Lebih lanjut, menurut anggapan Dave, seorang lakilaki yang berusia 17 itu adalah seorang laki-laki yang hampir bisa dibilang seorang "laki-laki", maksudnya disini adalah laki-laki yang matang. Dia juga menambahkan bahwa seorang lali-laki seperti dia seharusnya memiliki senjata api setelah dia bekerja keras (mendapatkan hasil dengan memiliki senjata api sebagai pengambaran seorang laki-laki sejati yang bekerja keras). kutnya:

Kemudian lihat kutipan beri-

"Lawd knows yuh don need no gun. But yer pa does. ",38

Dari kutipan diatas mengambarkan bahwa Dave belumlah pantas memiliki senjata api, akan tetapi sang ayahlah yang pantas. Hal ini dikarenakan ayah Dave belum memiliki senjata api untuk melindungi keluarganya. Kemudia setelah berhasil merengek dan diberi uang untuk membeli senjata api, Dave merasakan kekuatan dan kepercayaan dirinya. Lihat kutipan dibawah ini:

The first movement he made the following morning was to reach under his pillow for the gun. In the gray light of dawn he held it loosely, feeling a sense of power. Could kill a man with a gun like this. Kill anybody, black or white. And if he were holding his gun in his hand, nobody could run over him; they would have to respect him. It was a big gun, with a long barrel and a heavy handle. He raised and lowered it in his hand, marveling at its weight. ${ }^{39}$

Dalam pemikiran Dave setelah memiliki senjata api, dia akan

${ }^{38}$ Ibid., hlm. 262

${ }^{39}$ Ibid., hlm. 262 mendapatkan kekuatan yang bahkan menurtnya dia bisa menjadi ancaman buat siapa saja baik orang kulit hitam ataupun kulit putih. Mereka akan menghormatinya karena dia telah memiliki senjata api yang biasanya dipakai oleh laki-laki dewasa. Akan tetapi kemudian dia lupa bahwa senjata api itu juga merupakan sebuah tanggung jawab baru yang besar. Senjata api bukanlah sebuah mainan yang tidak akan membahayakan iwa orang lain akan tetapi sebuah alat pertahanan diri yang dengannya bisa melukai atau bahkan menghilangkan nyawa seseorang atau sesuatu. Akan tetapi kemudian setelah mengenggam senjata apinya malah justru memunculkan sikap childish Dave kembali yang ingin mempergunakannya untuk menembak tanpa tahu bagaimana cara menembak yang benar.

Dave walked off about twenty feet, held the gun far out from him at arm's length, and turned his head. Hell, he told himself, Ah am afraid. The gun felt loose in his fingers; he waved it wildly for a moment. The he shut his eyes and tightened his forefinger. Bloom! ${ }^{40}$

Dave menembak dengan memalingkan muka, menutup mata, dan jari telunjuknya kuat ke pelatuk. Kemudian teryata Jenny si keledai tua tertembak akibat kecerobohan Dave saat menembak yang tidak memperhatikan arah. Kemudian Dave harus bertanggung jawab dan menganti kerugian majikannya dengan memberinya pengantian atas kesalahannya berupa kerja dan setiap bulannya dia harus memberikan gajinya (dua dolar) kepada majikannya untuk mencicil keledai yang mati sebagai bentuk tanggung jawabnya.

Senjata api yang menurut Dave Saunders adalah segalanya untuk mendapatkan kehormatan (dihargai) dan sebagai simbol dari kedewasaanya, justru berubah menjadi petaka baru baginya. Setelah mengalami peristiwa mengerikan itu, Dave justru berubah menjadi laki-

${ }^{40}$ Ibid., hlm. 263 
laki yang sebenarnya yaitu pemberani. Maskulinitas bisa tercapai apabila selfexpression atau ekspresi diri dipakai untuk memperlihatkan eksistensi. ${ }^{41}$ Lihat kutipan dibawah ini:

He clutched the gun stiff and hard in his fingers. But, as soon as he wanted to pull the trigger, he shut his eyes and turned his head. Naw, Ah can't shoot wid mah eyes closed $n$ mah head turned.

With effort he held his eyes open; then he squeezed. Blooooom! He was stiff, not breathing. The gun was still in his hands. Dammit, he'd done it! He fired again. Blooooom! He smiled. Bloooom! Blooooom! Click, click. There! It was empty If anybody could shoot a gun, he could. He put the gun into his hip pocket and started across the fields. ${ }^{42}$

Dave telah belajar dari pengalamannya (saat menembak Jenny) untuk membuka mata dan fokus pada apa yang akan dia tembak. Dengan kata lain terlihat jelas dia mulai mempelajari bahwa dengan membuka mata dan menghadapi kenyataan akan membuatnya belajar dan tahu tentang cara menembak yang benar. Belajar mencoba sesuatu yang baru tanpa mengetahui resiko adalah konyol dan belajar dari pengalaman baik dari dirinya sendiri maupun orang lain adalah hal yang dilakukannya. Hal ini menunjukan proses maskulinitas atau proses sosial menuju sebuah kematangan seorang laki-laki meskipun hanya dari satu hal.

Akan tetapi sayangnya masih adal satu proses sosial yang masih belum dilakukan oleh Dave; tanggung jawab. Tanggung jawab yang dimaksud adalah kematian Jenny yang menjadi tanggung jawabnya. Lebih lanjut, diakhir cerita dia justru meninggalkan semuanya dan kabur ke suatu tempat yang tidak disebutkan.

\footnotetext{
${ }^{41}$ Charlotte Perkin Gilman, The Man-Made World or Our Androcentric Culture. Dodo Press, 1911. http://www.free-ebooks.net/ebook/The-ManMade-World.pdf. hlm. 29, diakses 28 Mei 2013.

${ }^{42}$ Ibid., hlm. 265
}

\section{Kesimpulan}

Maskulinitas laki-laki tidak bisa diukur sama pada setiap individu. Hal ini dikarenakan setiap laki-laki memiliki lingkungan dan budayanya masingmasing. Ketika budaya bergerak ke satu sisi, efeknya tidak hanya satu macam akan tetapi beraneka ragam tergantung pada lingkungan dan situasi budayanya.

Dalam cerita pendek The Man Who Was Almost a Man karya Richard Wright ini mengambarkan kehidupan Dave Saunders yang sangat dipengaruhi oleh lingkungan dan budayanya. Sisi kekanakan dari karakter utama mempengaruhi segala tingkah dan pemikirannya akan sesuatu hal yang dilakukannya. Lingkungan sekitar yang meremehkan dia membuat dia tertekan dan mencari cara untuk mengatasinya. Senjata api kemudian dipilih sebagai bentuk pendukung maskulinitasnya.

Dari semua kejadian bisa ditarik kesimpulan bahwa teryata tidak semudah itu untuk menaikan identitas atau citra diri dari seseorang. Lebih dibutuhkan kematangan berfikir (ilmu yang cukup dan pengalaman yang memadai) dan tanggung jawab dalam menaikan maskulinitas seseorang.

\section{Daftar Pustaka}

Bourdieu, Pierre, Dominasi Maskulin (Terj.), Jalasutra, Yogyakarta, 2010.

Darwin, Muhadjir. "Maskulinitas: Posisi

Laki-Laki dalam Masyarakat

Patriarkis" Center for

Population and Policy Studies

Gadjah Mada University. S.281,

June 24, 1999.

http://www.cpps.or.id/images/S2 81.pdf

Gilman, Charlotte Perkin, The ManMade World or Our Androcentric Culture. Dodo Press, 1911, http://www.freeebooks.net/ebook/The-ManMade-World.pdf, diakses 28 
Mei 2013

Jacobs, James B., Can Gun Control Work?, New York, Oxford University Press. Inc, 2002.

Kimmel, Michael S., "Masculinity as Homophobia: Fear, Shame, and Silence in the Construction of Gender Identity", Michael Kaufman dan Harry Brod, Theorizing Masculinities, Sage Publications, London, 1994.

Kusumadewi, Anggi dan Priliawito, Eko, Klewang, dari Brebes Jadi Raja Geng Motor Pekanbaru: Klewang adalah senjata tajam sejenis golok atau parang. Vivanews, Rabu, 15 Mei 2013, 06:15, http://www.viva.co.id/news/read /412754-klewang--dari-brebesjadi-raja-geng-motor-pekanbaru, diakses 22 Juni 2013.

Levant, Ronald F., "Men and Masculinity" Encyclopedia of Women and Gender: Sex Similariies and Differences and the Impat of Society on Gender. United States of America, Academic Press, 2002, hlm. 717-727.

MacInnes, J., The End of Masculinity, Buckingham, Open University Press, 1998.

Page, Ella, Men, Masculinity and Guns: Can We Break the Link? www.iansa.org/women, diakses 10 Juni 2013.

Espejo, Roman, American Youth: Opposing Viewpoints, United States of America, Greenhaven Press, 2003.

Reeser, Todd W., Masculinities in Theory: An Introduction, West Sussex, Wiley Blackwell, 2010.

Ritzer, George and Goodman, Douglas J., Teori Sosiologi Modern (terj), diterjemahkan oleh Alimandan, Jakarta, Prenada Media, 2005, Cet. Ke-5.

Storey, John, Teori Budaya dan Budaya
Pop (terj), diterjemahkan oleh Elli El Fajri, Qalam, Yogyakarta, 2004.

Tasker, Yvonne, Spectacular Bodies: Gender, Genre and the Action Cinema. New York, Routledge, 1993.

Young, Jeffrey, Gun Control Laws Fail To Keep Mentally Ill Away From Guns, terbit di website 17 Desember 2012 pukul 8:18, http://www.huffingtonpost.com /2012/12/17/gun-controlmental-

illness_n_2318421.html, diakses 24 Juni 2013.

Oxford Dictionaries. The World's Most Trusted Dictionaries, http://oxforddictionaries.com/d efinition/english/boy, diakses 23 Juni 2013.

The American Short Story Volume I, New York, Dell Publishing Co. Inc, 1977, hlm. 260-265.

Free Merriam Webster

Dictionary,

http://www.merriam-

webster.com/dictionary/weapon , diakses 11 Juni 2013.

Museum Pusaka

http://www.tamanmini.com/mu seum/museum-pusaka-2, diakses 23 Juni 2013.

\section{Documentary Film:}

Michael Moore, Bowling for Columbine, United Artist, United States of America, 2002, 119 menit. 

